\title{
Relationship between Work-Family and Interpersonal Conflicts: Mediating Role of Psychological Distress and the Moderating Effect of Islamic Work Ethics
}

\author{
Abdul Qayyum ${ }^{1 *}$, Sadia Kousar ${ }^{2}$, Raja Ahmed Jamil ${ }^{3}$, Muhammad Sarmad ${ }^{4}$ \\ ${ }^{1}$ Assistant Professor, Faculty of Management Sciences, Riphah International University, Islamabad, Pakistan \\ ${ }^{2}$ MS Scholar, FMS, Riphah International University, Islamabad, Pakistan \\ ${ }^{3} \mathrm{PhD}$ Scholar, FMS, Riphah International University, Islamabad, Pakistan \\ ${ }^{4}$ Assistant Professor, FMS, Riphah International University, Islamabad, Pakistan
}

\section{Keywords}

Islamic Work Ethics (IWE)

Work Family Conflict Interpersonal Conflict (IC)

Psychological Distress (PD)

Received: 19 March 2018

Accepted: 05 April 2018

\begin{abstract}
This study has been carried out to examine the association between work family conflict, PD and IC with moderating role of IWE. Self-administered questionnaires were distributed and data of 262 medical practitioners were collected for this study. Confirmatory Factor Analysis (CFA) and Structural Equation Modeling (SEM) techniques have been used to analyze the data. The results show that work family conflict has a positive effect on PD and IC. The study finds that presence of IWE plays a moderating role by weakening the relationship between PD and IC. Results also show that PD mediates the relationship between work family conflict and IC.
\end{abstract}

KAUJIE Classification: $\mathrm{H} 48$, T6

JEL Classification: D74, M12, M5

(C) 2018 JIBM. All rights reserved.

\section{INTRODUCTION}

Two of the vital facets of a person's adulthood are family and work. However, fast paced life of modern era makes both of these domains somewhat incompatible. Therefore, a conflict becomes inevitable, given the role expectations of these two domains. The studies have shown that these conflicts lead to numerous detrimental outcomes such as job burnout, dissatisfaction at job, employees' turnover as well as IC and workplace aggression (Frone, Russell, \& Cooper, 1992; Greenhaus \& Beutell, 1985; Gutek, Searle, \& Klepa, 1991; Wang, Liu, Wang, \& Wang, 2012). IC has been defined as "negative interpersonal encounters involving covert hostility and contentious and angry exchanges between individuals within an organization" (Keenan \& Newton, 1985). Due to higher competition in employment situations, work-life conflict has become more prevalent, resulting in IC and aggression at

\footnotetext{
${ }^{*}$ Corresponding author: Abdul Qayyum
}

†Email: abdul.qayyum@ riphah.edu.pk 
workplace (Frone et al., 1992; Netemeyer Boles, \& McMurrian, 1996; Wang et al., 2012). It is important to achieve a balance between these two vital facets. Individuals come across more conflicts between job and personal life when they continue following the urge for quality of life that they crave for (Casper, Harris, Taylor-Bianco, \& Wayne, 2011).

Another key outcome of work-life conflict is PD that is a state of emotional suffering characterized by symptoms of depression (e.g., lost interest, sadness, hopelessness); and anxiety (Mirowsky \& Ross, 2002). According to Lazarus and Folkman's (1984), a person's ability to handle stress situation depends exquisitely upon his/her thinking, perception and motivation. It is possible that a person does nothing harmful at all, yet it affects his/her mental capabilities in the long run, which would ultimately affect his/her job performance (Restubog, Scott, \& Zagenczyk, 2011). Such stress and anxiety can spill over at workplace affecting one's behavior, and ultimately the performance (Leiter \& Durup, 1996). One such type of abusive behavior is called IC. IC is a phenomenon that occurs between interdependent parties as they experience negative emotional reactions to perceived disagreements and interference with the attainment of their goals (Barki \& Hartwick, 2001). It can occur amongst people who are victim of some frustration or facing some pressures at workplace due to misunderstanding or disagreements between coworkers (Harris et al., 2011; Penney $\&$ Spector, 2005).

Beekun (1997) defined IWE as a set of principles which help differentiate between right and wrong. To put in other words, it is what a person thinks of as appropriate to do or say. IWE refer to orientation towards work, and Islam treats ethical behaviors at work place as a virtue (Rizk, 2008). In Islam, work ethics solely rely on the teachings and guidance of Islam; what Allah say and has taught us via Hazrat Muhammad (PBUH). Studies of Ali (1988) and Rizk (2008) reaffirm that IWE concept originates from Holy Qur'ān, and teachings of Holy Prophet (PBUH). The Prophet taught us that sins are forgiven for those who work hard and it is legacy of four pious Caliphs of Islamic era. The Prophet also said, "I have been sent for the purpose of perfecting good morals" (Ibn Hambal, No: 8595)

IWE have been researchers' focus of attention for a while. For example, it has been found to be associated with job satisfaction and organizational commitment, (Rokhman, 2010; Yousef, 2001). Others studied IWE in the context of attitude towards organizational change (Yousef, 2000), motivation (Hayati \& Caniago, 2012), and other HR domain variables such as locus of control, role conflict and role ambiguity (Yousef, 2000). It is clear from the above discussion that 'IWE' is an imperative variable with implications for managers and researchers. However, it is important to note that focus of these studies has been other job related outcomes (e.g., job satisfaction, organizational commitment, change, etc.) rather than job stress and employees' wellbeing. Of course, a few studies have explored the relationship of IWE with stress and employees' wellbeing such as Din and Farooq (2016) and Ajmal and Irfan (2014). These studies provide some reference to the contextual role played by IWE, yet the studies are rare and the contextual role of IWE with PD and conflict is still to be explored for proper guidance for the practitioners.

In the lights of above discussion, it is clear that work-family conflict leads to PD which in turn results in various detrimental outcomes. Therefore, one of the objectives of study 
is to investigate the link between work-family and IC mediated by PD. This relationship has been left ignored in past studies. Furthermore, the role of IWE in reducing stress and conflict has not be explored in past studies to the best of this study's researchers knowledge. In the case of doctors and medical practitioners, the case of work life conflict becomes even more important. Medical practitioners, being one of the key constituents of any economy and society, are most stressed individuals, who are prone to work life conflict (Machi et al., 2015). Therefore, a study to understand their work life conflict and to propose possible remedies is warranted.

Therefore, this study makes important contribution to the literature on work-family conflict and IWE. It contributes by tapping into the relationship between work-life conflict and IC mediated by PD. Besides, it tests for the moderating role of IWE between PD and IC.

\section{LITERATURE REVIEW AND HYPOTHESES DEVELOPMENT}

This section discusses the key variables used in this study and eventually leads to the development of hypotheses set forth.

\section{Work Family Conflict and IC}

The work and family intermix has become a topic of greater interest in the psychological research. Significant and rapid changes occurred in the configuration of the workforce such as significant increase in women's workforce participation as well as the greater number of couples in which both of the partners having paid occupation (Major \& Germano, 2006). Most recently, French, Dumani, Allen, and Shockley (2018) established that apart from dual-working couples, increased use of technology and cross-national work also cause work family conflicts. Kahn, Wolfe, Quinn, Snoek, and Rosenthal (1964) first proposed the concept of work-family conflict that can be defined as "the role that might get conflicting and the pressure that is being triggered due to inconsistency at some level among the employment and domestic factors", which proceeds to the conflict at work life and personal life interface. Frone et al. (1992) directed that work-family conflict was a two-way concept, and possibly could break up into two conditions - either job that is interfered with household, or household that is interfered with job. When household troubles and liabilities meddle with work place fatigue, the unfinished job fatigue, in return, might meddle with home sweet home. On other side of the coin, when the troubles and burdens of job intrude with the functioning of household errands, the household errands would, in response, get involved with the job. Therefore, as an outcome of the modern life, individuals tend to experience very high levels of stress that ultimately lead to an adverse impact on their emotional, physiological, cognitive and behavioral state.

In a common practice, IC that occurs at work is a state of depression which results in minor arguments, scattering rumors and gossiping (Spector \& Jex, 1998). More explicitly, the IC is defined by the researchers as "an organizational stressor that consists of differences among individuals in the workplace". Conflicts that take place at the workplace might lead to generating the unsympathetic environments that pave a way for the additional demands on 
part of the employees. Those who suffer IC at work often prefer to use the emotion regulation and rational thinking in order to cope up with the feelings of annoyance and antagonism; the direct outcome of the conflict. These strategies may leave them feeling shattered and incapable to deal with the additional demands at work or home (Alicia, 2000); in some cases, it may give rise to workplace bullying (Agotnes, Einarsen, Hetland, \& Skogstad, 2018).

Extant literature supports interplay between work family conflict and IC. Frone et al. (1992) found positive and consistent relationship between work family conflict and depression. While conducting a study on the relationship between work family conflict and its outcomes, Wang et al. (2012) also found that presence of conflict in family and work relations did influence aggressive behavior at work place. Other past studies also suggest that work family conflict is positively related to conflict at workplace (Netemeyer et al., 1996).

\section{Work Family Conflict and PD}

Greenhaus and Beutell (1985, p. 77) define work-family conflict as "a form of inter role conflict in which the role pressures from the work and family domains are mutually incompatible in some contexts." PD is mostly termed as a state of emotional suffering characterized by symptoms of depression (e.g., lost interest; sadness; hopelessness) and anxiety (e.g., restlessness; feeling tense) (Mirowsky \& Ross 2002). Some studies have found that work family conflict envisages PD (Holmes \& Rahe, 1967; Kobasa, 1979; Wang et al., 2012).

A typical conflict between work and family arises when one role collides with another (Greenhaus \& Beutell, 1985). This inter role conflict can take two ways (Frone, 2003). The job task can interfere With the Family Task (WIF), or the family task can interfere with the job task (FIW). It is really essential for every individual to stay calm and in a healthy mental state in order to be well prepared for anything forthcoming in life. Stress of losing someone close or any kind of the failure may cause a high impact on mental as well as physical health (Holmes \& Rahe, 1967; Kobasa, 1979). Personanty literature suggests some people are always mentally prepared to face sudden situations, which is a personality trait of few ones. Work family conflict can be the root of major stress and clashes. Probable aftermaths of work-family conflict can be split into three definite classifications: work-related, familyrelated, and domain-unspecific outcomes (Bellavia \& Frone, 2005). Ahmad (2008) has justifiably studied that the work family conflict has harmful impact on employee's execution levels. Stress or frustration from the side of family can be very problematic (Lim, Cortina, $\&$ Magley, 2008). This makes people go down, get into isolation, more prone to anger and lack of creative thinking (Pearson, Andersson, \& Wegner, 2001).

The conservation of resource theory is a must to be mentioned here. It is a stress theory that describes the motivation that drives humans to both maintain their current resources and to pursue new resources (Hobfoll, 1989). When translated into the context of this paper, it states that when people run into conflict, they not only lose performance and get worried about their work, but they also fear of losing their valuable resources. Another key theory to mention here is spill over theory; which explains the conditions under which the spillover between work and family could be either positive or negative. The spillover is expected to be negative when work and family interaction are rigidly structured. While on the other 
hand, if there is flexibility between work and family, the spillover could be positive and would help to achieve work life balance (Hill, Ferris, \& Martinson, 2003). In the context of current study, when family tasks are not accomplished at home they are brought to workplace, and an unconscious attention diversion occurs. As a result, workplace gets neglected and performance graph falls down affecting one's performance. This phenomenon is also known as procrastination (Pearson et al. 2001). Hence, we hypothesize:

H1: Work family conflict affects the PD positively and significantly.

\section{PD and IC}

The existence of PD has been recognized for thousands of years. Whenever someone is exposed to the stress, he/she first tries to cope up with it by resisting it. When it continues and body keeps on trying to resist, it leads to exhaustion. Long term explosion to stress can lead to physical dis-functioning which ultimately leads to a disease (Baum, Singer, \& Baum, 1981). More recently, Letellier et al. (2018) argued that presence of adverse psychosocial work elements results in an increased level of PD. Continuous PD can decrease one's motivation and abilities to perform outclass in comparison with others (Hockey, 1997). Stress or frustration from side of family can be very problematic (Lim et al., 2008). People's response to the event or object of stress is also very important, how they may react is all dependent upon how much they feel frightened or endangered (Lazarus, 1966).

IC that occurs at work manifests itself in minor arguments, scattering rumors and gossiping (Spector \& Jex, 1998). These strategies may leave them feeling shattered and also incapable to deal with the additional demands at work or home (Alicia, 2000) and in some cases, it may give rise to workplace bullying (Agotnes et al., 2018). Human beings naturally form the groups and try to differentiate their respective group from those of the outsiders. This might lead to the possible conflict among races, religions, political systems and even teams or departments at work, thus just to make some people feel out of the place.

Family is said to be the backbone of every person's upbringing and personality, if one is not happy or stable in its family environment he will be very prone to anger, frustration, temper, which can lead to negative outcomes (Gibbons, Dempster, \& Moutray, 2011). And IC is one such negative outcome. Cortina, Magley, Williams, and Langhout (2001) also stated that stress situations can lead to negative outcomes as mental disorder, serious deviant behavior and doing negative behaviors. Previously, Keenan and Newton (1985) and Spector and Jex (1998) also stated that the concepts of stress and IC are associated with each other. Therefore, we propose that:

H2: PD affects the IC positively and significantly.

\section{Moderating Role of IWE}

Discussion on IWE was initiated by Ali (1988). The term 'IWE' has been drawn from Weber's theory of protestant work ethics (Ajmal \& Irfan, 2014). IWE can be explained as the collective array of ethical ideologies that separate between incorrect and correct in the Islamic framework (Beekun, 1997). Rizk (2008) has explained the concept of IWE as an orientation that points towards the virtue of work in human lives. IWE in crux refers to act- 
ing upon the teachings of Muhammad (PBUH) and the Qur'ān. The image of any company with IWE is very important for every organization. People make financial investment decisions based on this concept and customers' purchase decisions are also linked to it. People avoid buying products from company labelled as unethical or immorally wrong (Sadozai, Marri, Zaman, Yousufzai, \& Nas, 2013). Qur'ān says with regard to dealings with others, "Give full measure and full weight in justice, and wrong not people in respect of their goods" (Qur'ān 11:85).

IWE are related to employees' performance and their well-being. It includes mental wellbeing, coping with workloads and stress (Ajmal \& Irfan, 2014; Mohamed, Karim, \& Hussein, 2010; Nasr, 1984). Prophet Muhammad (PBUH) said that sins are waived off by hard work, and the food ate by a person by hard work is the best food (Ali, 1992). Previous researches have focused on just job performance or satisfaction; this research has been narrowed down and its variables are tested in light of the previous researches. The studies have shown and proved that work ethics are strongly related to one's mental or psychological state.

Islam has provided the simple and widespread knowledge that is purely based on the ethics. It tends to regulate every aspect related to life. For instance, it includes the setup of work in accounting, social and economic activities (Naqvi, 1981). IWE possibly spell out as the collective array of ethical ideologies that bifurcate the do's and don'ts of the Islamic framework. The IWE lead to an orientation that points towards the virtue of work in human lives. According to the IWE setup, the success and achieving the peace of mind is known to be achieved with work. Moreover, the employee's turnover intent can also be predicated by IWE related research. IWE oriented employees generally show lesser turnover behavior. Therefore, it can be considered as the believable fact that such employees who follow the IWE, show lesser turnover intention, they are more satisfied with their job, tend to show high job involvement and don't become victim of PD. Hence, they are less involved in the IC at work place (Ahmad, 2011).

IWE are generally derived from the intentions while doing the work, instead of the results of work. In order to have a welfare society, it is really important to have the necessary measures of the provision of full justice and generosity at the work place. The competition in work has also been seen as the improvement in work quality. Thus more precisely, IWE are obligatory for healthy life to earn money for the survival of life. According to IWE, work is kind of a noble deed as it fulfills the necessities for survival and maintains equilibrium in individual and social life. Work is associated to give the man a sense of independence, self-respect, satisfaction, pleasure and fulfillment of the purpose of life. IWE tend to reduce the problems of society and encourage commitment. If each person is committed to his job and avoids unethical methods of wealth accumulation, it would lead to the healthy working environment and lesser IC that ultimately lead to a healthy and stress free life. This also brings good balance of work and life (Ahmad, 2011). The extant literature does support the argument that IWE play a contextual role in job and work related studies. For example, Rawwas Javed and Iqbal (2018) found that IWE moderate the relationship between perception of politics and negligent workplace behavior in the way that relationship would be 
weaker when IWE are higher.

Previous sections discussed that work life conflict leads to PD and is associated with IC. However, previous studies' results are mixed. For example, some studies failed to establish a relationship between work life conflict and negative job related outcomes (Anwar \& Shahzad, 2011; Bhuian Menguc, \& Borsboom, 2005; Netemeyer et al., 1996). Together, the controversies in the relationship between work life conflict and negative job related outcomes suggest the possibility of the presence of personal or contextual factors that may moderate these relationships (Colquitt, Scott, Judge, \& Shaw, 2006). Since the IWE are a source of inner satisfaction, IWE may be an important moderator in the relationship between stress and negative job outcomes. Hence, we hypothesize:

H3: IWE moderate the relationship between PD and IC in such a way that it weakens the relationship.

\section{Mediating Role of PD}

PD has an intense impact on the overall work performance of the individuals. The factors which cause the PD are being found highly related to the various factors at work place like over-time exertion, pressure exerted regarding the goal attainment, which might be attributed to burden of responsibilities. Personal life events that lead to psychological stress can be ultimately resulting in the work outcomes, the most important of which is the conflict with other people at work (Bhagat, 1983). Actually, the experiences in one domain, such as the family, are very much responsible in casting the spillover to affect the mood and behavior in another domain such as the workplace. Studies have shown that the family stress might prevent workers from fulfilling their job responsibilities (Ford, Heinen, \& Langkamer, 2007).

Employees who are the sufferers of imbalance in work to life balance might continue pondering and worrying during their job, thus making them negligent to work tasks. Family members might demand warmhearted communication from the employee, but various roles clash makes person incapable to various roles expectancy. Bartolome (1972) believed that many young managers have been subjected to two phases that may possibly not be in line with each other. Thus it may possibly be hard to regard both aspects simultaneously. The existence of imbalance in work and personal lives of the employees has resulted in higher ICs and lack of focus by the employees, and high turnover rates. The workers' abilities to achieve the critical goals of work have been declined due to PD (Brummelhuis \& Bakker, 2012).

The objective of flexible work arrangements is reducing the inter-role conflict that could be caused by the PD factor created at work. It also seems reasonable to assume that flexible arrangements would be attractive to workers. Particularly for those who are facing the competing demand of two domains (Rau \& Hyland, 2002). Hence, the problem of work life balance needed to get fixed (Yasbek, 2004). Hudson (2005) took into account that work life balance was a predecessor of organizational commitment. Organizations must devise and then implement such practices and benefits that would help employees balance their work and lives (e.g., flexible work schedules etc.), because it has been found that the job-related 
tension has a causal impact on the ICs through PD which then influences turnover intentions (Kemery, Mossholder, \& Bedeian, 1987). Hence, the hypothesis:

H4: PD mediates the relationship between work family conflict and IC.

On the basis of above formulated hypotheses, theoretical framework of the study is given below in Figure 1.

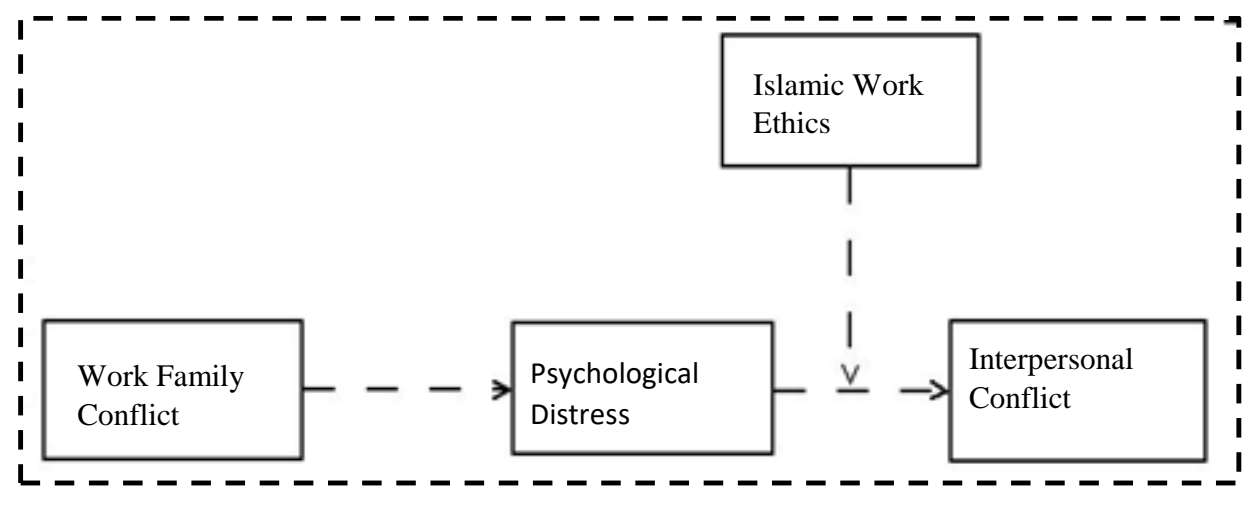

FIGURE 1. Conceptual Framework

\section{RESEARCH METHODOLOGY}

This portion discusses the methodology adopted for the study; includes sampling, measures adopted as well as reliabilities of measure and correlations. Some useful demographics have also been discussed.

\section{Population and Sampling}

The population of the study are the medical practitioners. Medical practitioners have been considered one of the most stressed individuals due to overwork. Hence, there has been higher prevalence of work life conflict among them (Mache et al., 2015; Wang et al., 2012). Due to time and cost considerations, the researchers used a convenience sampling for this study and initially distributed 300 questionnaires. Sample size of 300 was chosen on the basis of method suggested by Sekaran and Bougie (2016). According to their suggestion, if the population is 10000 , the ideal sample size should be 260 . In the twin cities (Rawalpindi/Islamabad) there are no more than 10000 medical practitioners; it is, therefore, an appropriate sample size.

Out of 300 questionnaires initially distributed, 262 (87 percent response rate) were returned in usable form with male respondents $66.4 \%$ and females $33.6 \%$. Most of the respondents had age between 15 and 35, comprising about 85\%. As far as marital status is concerned, $53.3 \%$ people were single, while $44.3 \%$ were married. It can be observed that most of the doctors included in the study are young and have begun their careers. Therefore, $88.2 \%$ had less than or equal to 10 years' experience, $8.8 \%$ had 11 to 20 years of experience, $1.1 \%$ had 31 to 40 years of experience.

\section{Measures}

All the study variables have been measured on a 5 point Likert scale ranging from Strongly 
Disagreed $=1$ to strongly agree $=5$ or Not at all $=1$ and many times $=5$.

PD was measured using 5 item scale adopted from Restubog et al., (2011). Work family conflict is measured using 5 item scale adopted from Netemeyer et al. (1996). IWE have been measured using 16 item scale by (Ali, 1992). The Cronbach's Alpha values for all adopted scales are presented in Table 1.

TABLE 1

Reliability Analysis

\begin{tabular}{ll}
\hline \hline Variables & Cronbach alpha \\
\hline Work family conflict & 0.882 \\
PD & 0.827 \\
IC & 0.806 \\
IWE & 0.841 \\
\hline \hline
\end{tabular}

\section{RESULTS}

We analyzed the data using a procedure of maximum likelihood using IBM, SPSS, AMOS 21. The assessment of the structural model follows the two-stage analytic technique, confirmatory factor analysis/ measurement model followed by structural model.

\section{Correlations}

Table 2 presents the correlations between the variables used in the study. According to the rule, a low correlation exists among variables when $r$ is between 0.10 to 0.29 or -0.10 to -0.29. A moderate correlation exists when $r$ is between 0.30 to 0.49 or -0.30 to -0.4 .9 . And a strong correlation exists when $r$ is between 0.50 to 1.0 or -0.50 to -1.0 (Cohen, 2013). The correlation between work life conflict and PD is .408 indicating a strong positive relationship. Similarly, the correlation between PD and IC is .581 indicating a strong positive relationship between them as well. Furthermore, the negative correlation values of IWE with all other variables also hints about their proposed negative moderating role.

TABLE 2

Correlations

\begin{tabular}{llllll}
\hline \hline S. No. & Variables & 1 & 2 & 3 & 4 \\
\hline 1 & Work family conflict & 1 & & & \\
2 & PD & $.408^{* *}$ & 1 & & \\
3 & IC & $.271^{* *}$ & $.581^{* * *}$ & 1 & \\
4 & IWE & -.218 & $-.357^{*}$ & $-.425^{* *}$ & 1 \\
\hline **. Correlation is significant at the 0.01 level (2-tailed). & & \\
*. Correlation is significant at the 0.05 level (2-tailed). & &
\end{tabular}

\section{Measurement Model}

Before performing SEM, some pre-requisite assumptions have to be met. For this study, the pre-requisite assumptions as suggested by Dastgeer, Rehman, and Rehman (2012) were met: it was ensured that no issues were existent in terms of missing data, outliers, skewness/kurtosis, normality, linearity, and multicollinearity. 
An important parameter of confirmatory factor analysis is the estimation of standardized factor loading or constructs loadings. Hair, Black, Babin, Anderson, and Tatham (2006) proposed the deletion of variables which violate the limit of standardized factor loadings by 1.00, or near to it. In order to ensure this limit value is not exceeding, Hair et al. (2006) also suggested setting a very small error variance value of 0.005 . Table 3 shows that all the loadings were significant, with no item having the loading so low to be deleted.

Convergent validity was examined using Average Variance Extracted (AVE) and Composite Reliability (CR). According to Fornell and Larcker (1981), the values of AVE and CR should be about 0.50 and 0.70, respectively. As seen in Table 2, the CR and AVE values range from 0.823 to 0.955 , while AVE values range from 0.524 to 0.631 . As far as discriminant validity is concerned, it can be tested when the square root of AVE of each construct is greater than the correlation with itself and other constructs. The AVE values for work family conflict, PD, IC and IWE are $0.72,0.79,0.73$ and 0.76 respectively. All these values are greater the correlations with itself and other constructs.

TABLE 3

Construct Loadings, AVE and CR

\begin{tabular}{|c|c|c|}
\hline Construct & Items & Loadings \\
\hline \multirow[t]{6}{*}{ Work family conflict AVE 0.524 CR 0.867} & WFCl & $0.726 * * *$ \\
\hline & WFC2 & $0.848 * * *$ \\
\hline & WFC3 & $0.772 * * *$ \\
\hline & WFC4 & $0.669 * * *$ \\
\hline & WFC5 & $0.632 * * *$ \\
\hline & WFC6 & $0.676^{* * *}$ \\
\hline \multirow[t]{4}{*}{ IC AVE 0.539 CR 0.823} & $\mathrm{ICl}$ & $0.670 * * *$ \\
\hline & IC2 & $0.767 * * *$ \\
\hline & IC3 & $0.754 * * *$ \\
\hline & IC4 & $0.743 * * *$ \\
\hline \multirow[t]{4}{*}{ PD AVE 0.631 CR 0.871} & PDl & $0.855^{* * *} *$ \\
\hline & PD2 & $0.841 * * *$ \\
\hline & PD3 & $0.745^{* * *}$ \\
\hline & PD4 & $0.729 * * *$ \\
\hline \multirow[t]{16}{*}{ IWE AVE 0.575 CR 0.955} & IWEl & $0.757 * * *$ \\
\hline & IWE2 & $0.702 * * *$ \\
\hline & IWE3 & $0.708 * * *$ \\
\hline & IWE4 & $0.834 * * *$ \\
\hline & IWE5 & $0.809 * * *$ \\
\hline & IWE6 & $0.765 * * *$ \\
\hline & IWE7 & $0.760 * * *$ \\
\hline & IWE8 & $0.752 * * *$ \\
\hline & IWE9 & $0.683 * * *$ \\
\hline & IWE10 & $0.803 * * *$ \\
\hline & IWEll & $0.799 * * *$ \\
\hline & IWE12 & $0.822 * * *$ \\
\hline & IWE13 & $0.721 * * *$ \\
\hline & IWE14 & $0.652 * * *$ \\
\hline & IWE15 & $0.719 * * *$ \\
\hline & IWE16 & $0.823 * * *$ \\
\hline
\end{tabular}


The measurement model has been estimated using structural equation modeling shown in Figure 2. The goodness-of-fit indices for the measurement model are Chi-square $=864.617$ ( $\mathrm{df}=399), p<0.00$. The Chi-square is significant, and the normed Chi-square value $\left(X^{2} / \mathrm{df}\right)$ is 2.167, which is within the suggested ratio of 2 to 3 as recommended by Fornell and Larcker (1981). Root Mean Square Error of Approximation (RMSEA) $=0.067$ indicates acceptable fit, which is below the suggested cut off value of 0.08 (MacCallum et al., 1996).

Goodness-of-Fit Index $(\mathrm{GFI})=0.92$; Tucker-Lewis Index $(\mathrm{TLI})=0.95$; and Comparative Fit Index $(\mathrm{CFI})=0.96$. All the values are above the cut off values $>=0.90$ suggested by Hooper, Coughlan, and Mullen (2008). We therefore interpret the overall model fit as acceptable.

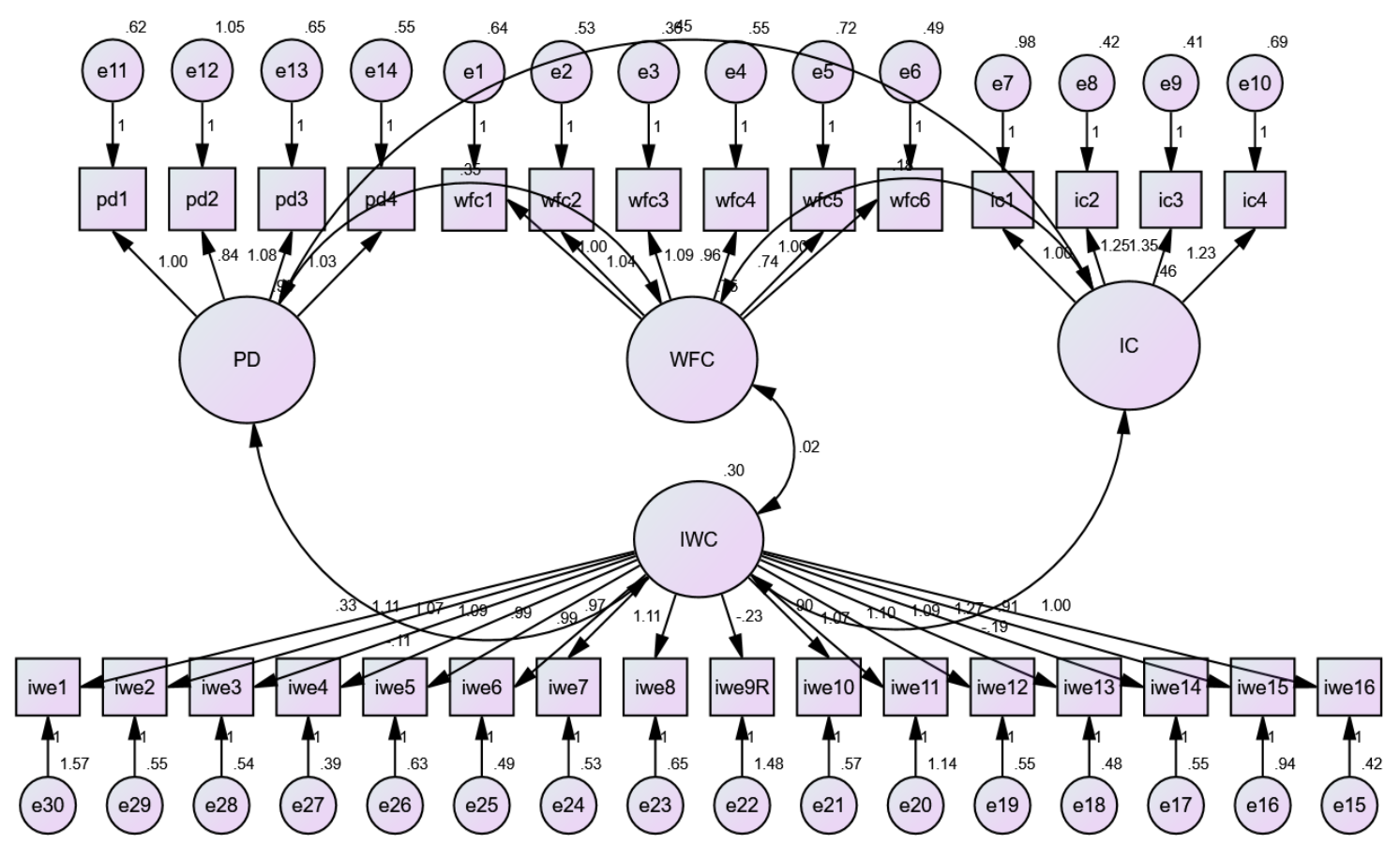

FIGURE 2. Measurement Model

\section{Structural Model}

Table 4 presents the results of the hypotheses testing ( $\mathrm{H} 1, \mathrm{H} 2$, and $\mathrm{H} 3)$, including path coefficients, critical ratio for regression weight (C.R.), and standard error of regression weight (S.E.) values for each structural path.

TABLE 4

Structural Parameter Estimates

\begin{tabular}{llllll}
\hline \hline Relationship & Hypothesis & Estimate & C.R. & S.E. & $p$ \\
\hline Work Family Conflict $\rightarrow$ PD & H1 & .470 & .065 & 7.226 & $* * *$ \\
PD $\rightarrow$ IC & H2 & .513 & .045 & 11.518 & $* * *$ \\
$(\mathrm{PD}$ x IWE) $\rightarrow$ IC & H4 & -.985 & .059 & -4.019 & $* * *$ \\
\hline \hline
\end{tabular}

Where $p$ value at $* * *$ indicates $p<0.001$

H1 predicted that work family conflict would have significant and positive effect on PD. Results show that work family conflict is significant and positive predictor of PD (path 
estimate $.470, p<0.001$ ). Thus $\mathrm{H} 1$ is supported. As predicted in $\mathrm{H} 2, \mathrm{PD}$ has been found to be a significant and positive predictor of IC (path estimate $.513, p<0.001$ ).

$\mathrm{H} 3$ proposed that the IWE would moderate the relationship between PD and IC. The interaction effects for this relationship were established (path estimate $-.985, p<0.001$ ), thus supporting the hypothesis. Figure 3 plots the interaction effects of IWE and PD on IC. The graph shows that IWE moderate the relationship between PD and IC such that higher the IWE, weaker the relationship between psychosocial distress and IC.

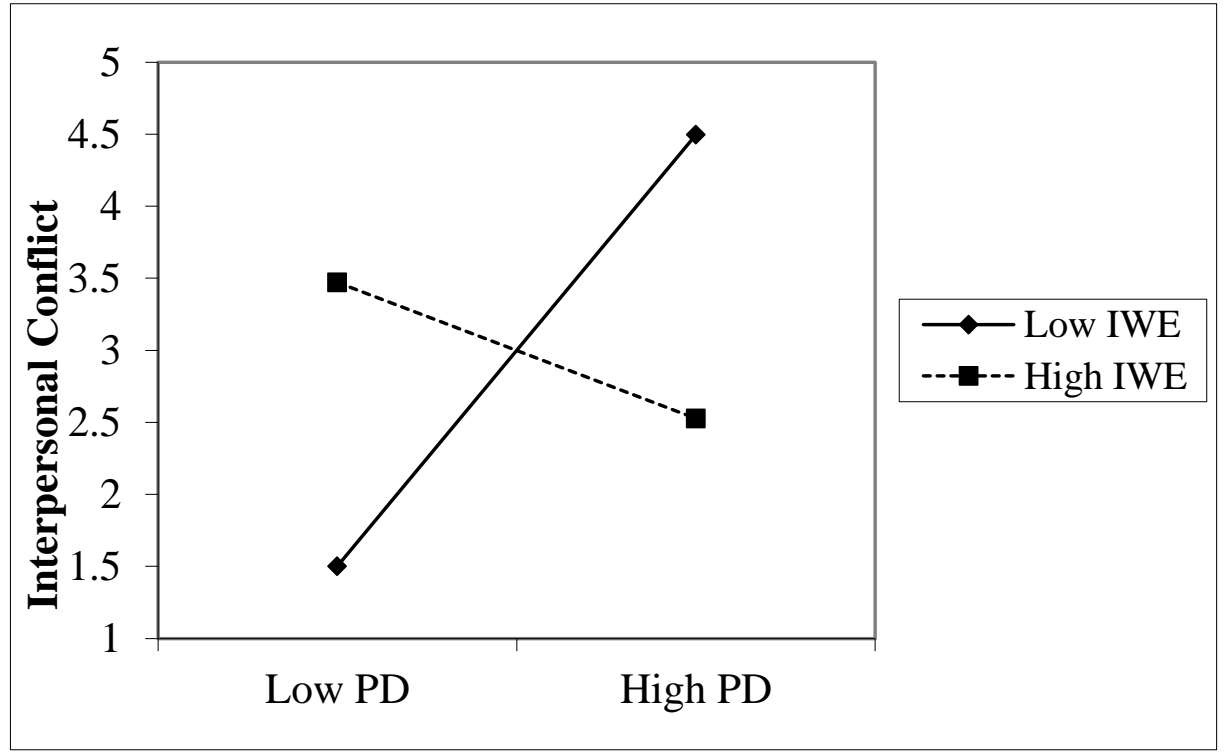

FIGURE 3. IWC moderates between PD and IC

As for the $\mathrm{H} 4$ is concerned, it was proposed that PD mediates the relationship between work family conflict and IC. Preacher and Hayes (2008) method has been used for this analysis. In this study 95 per cent confidence interval was obtained with 5000 bootstrap resamples (Preacher \& Hayes, 2008). The Figure 4 shows the outcome of mediation analysis performed.

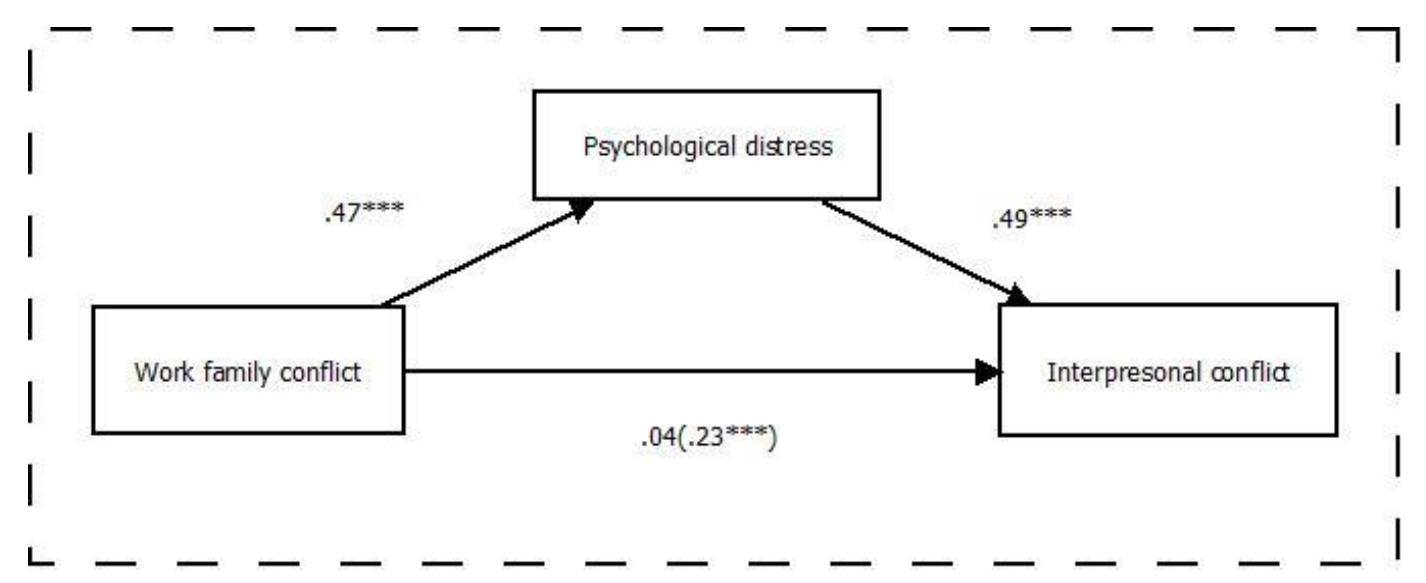

FIGURE 4. Mediation analysis

Table 5 summarizes the mediations analysis performed. First, it has been found that work family conflict is positively related to IC ( $\mathrm{B}=.2345, p=0.000)$. It is also found that work 
family conflict is positively associated with $\mathrm{PD}(\mathrm{B}=.4701, p=0.000)$. And finally, it is found that the mediator, $\mathrm{PD}$ is positively related to IC $(\mathrm{B}=.4988, p=0.000)$. Since both the $\mathrm{X}$ to $\mathrm{M}$ and $\mathrm{M}$ to $\mathrm{Y}$ paths are significant, mediation analysis is performed. The results reveal that PD plays a mediating role between the relationship of work family conflict and IC (Bootstrap SE $=.0411, \mathrm{CI}=.1608$ to .3233 ). It is also found that the direct effect of work family conflict on IC became insignificant $(\mathrm{B}=.0410)$ when controlling for PD which indicates a full mediation. Hence $\mathrm{H} 4$ is supported.

TABLE 5

Mediation Analysis

\begin{tabular}{lllll}
\hline \hline Outcome: PD & & & \\
& Coefficient & SE & T & $p$ \\
\hline Constant & 1.0512 & .2005 & 5.2425 & .0000 \\
Work family conflict & .4701 & .0652 & 7.2117 & .0000 \\
Outcome: IC & & & & \\
& Coefficient & SE & $\mathrm{T}$ & $p$ \\
Constant & .7717 & .1664 & 4.6361 & .0000 \\
PD & .4988 & .0490 & 10.1883 & .0000 \\
Work family conflict & .2345 & .0564 & .7266 & .0000 \\
Direct effect of X on Y & & & & \\
& Effect & SE & T & $p$ \\
Indirect effect of X on Y & .2345 & .0564 & .7266 & .0000 \\
& & & & \\
& Effect & Boot & SE BootLLCI & BootULCI \\
& .0410 & .0411 & .1608 & .3233 \\
\hline \hline
\end{tabular}

Where $p$ value at $* * *$ indicates $p<0.001$

\section{DISCUSSION AND CONCLUSION}

In this study, we tested work family conflict with IC mediated by PD. It also tested the moderating role of IWE at two instances. First, it tests whether IWE moderate the relationship between work family conflict and PD and second, it tests the moderating role of IWE between PD and IC.

H1, which states "work family conflict affects the PD positively and significantly" is accepted. The results are aligned with Holmes and Rahe (1967) and Kobasa (1979). When there is a clash between two roles or multiple responsibilities (whether family to work, or work to family) it increases the tension and stress level. Therefore, a person is not able to pay attention, which increases PD and performance of a person.

The conservation of resource theory is a must to be mentioned here. It is a stress theory that describes the motivation that drives humans to both maintain their current resources and to pursue new resources (Hobfoll, 1989). When translated into the context of this paper, it states that when people run into conflict, they not only lose performance and get worried about their work, but they also fear of losing their valuable resources. Another key theory 
worth mentioning here is spill over theory, which explains the conditions under which the spillover between work and family could be either positive or negative. The spillover is expected to be negative when work and family interactions are rigidly structured. While on the other hand, if there is flexibility between work and family, the spillover is positive and it would help to achieve work life balance (Hill et al., 2003). In the context of current study, when family tasks are not accomplished at home, they are brought to workplace and an unconscious attention diversion occurs. As a result, workplace gets neglected and performance graph falls down affecting one's performance. (Pearson et al. 2001).

$\mathrm{H} 2$ posited that $\mathrm{PD}$ affects the IC positively and significantly. This hypothesis is accepted and the results are in line with findings of Lim, and Tai (2014). They also found that work family conflict leads to PD, which in turn, ultimately leads to IC. When a person is depressed and is unable to think, the behavior of that person also changes. Therefore, if a person is not in a good state of mind, (s)he will not behave well, and a physical reaction might be generated (Ilies, Johnson, Judge, \& Keeney, 2011). H4 tested for the mediating role of PD between work family conflict and IC, and it was also accepted. Previously, Ford et al. (2007); Lim et al. (2008) found that work family conflict impacts on personal behaviors, leading to rude conversations and ultimately IC.

$\mathrm{H} 3$ posited that IWE negatively moderate the relationship between PD and IC. This hypothesis was also held true for the study. These results support the findings of previous studies by Ajmal and Irfan (2014), Mohamed et al., (2010), Nasr (1984) who found that IWE had not only a negative effect on PD, but the same also had a negative effect on the IC. Contrarily, presence of IWE leads to job satisfaction and organizational commitment (Rokhman, 2010; Yousef, 2001).

\section{Implications}

For practitioners, one of the key implications of this study is the role of IWE. It is important for the managers to develop and retain an environment in which all personnel implement IWE at the organizations. This will help not only to reduce PD caused by work family conflict, but would also mitigate the IC. Ultimately, presence of IWE environment would lead to better job satisfaction and higher organizational commitment. In sum, presence of IWE at an organization reduces stress and conflict which in turn leads to better employee's satisfaction, commitment and overall performance.

This study contributes toward highlighting the other side of the picture and suggests that organizations can come up with a system to identify distress at the earlier stage and thus referring the affected to a psychologist for help. Furthermore, organization can make it compulsory for the employees to participate in recreational activities along with family and spend sufficient time with family. This is a two-way process, if employer cares for its employees, ultimately employers will be rewarded in the form of better job performance.

For researchers, this study provides important insights into the relationship of work family conflict and its outcomes. From the results of this study and findings of previous researches, it has been observed that work family conflict leads towards low job performance and serious mental health issues. Therefore, the more this phenomenon is neglected, the 
more difficult it becomes to resolve. And it ultimately costs both the organization and the individuals.

\section{Limitations and Future Directions}

Like every research, our study has also some limitations. First, due to limited time frame for data collection, the sample size was relatively small. Future study could work on larger sample sizes to increase the generalizability of findings. Second, data were collected from medical practitioners of twin cities only. Future researchers can collect data from different professions like teachers and engineers to test/extend the applicability of this model. Third, the term family is yet to be defined as it is treated differently in different cultural setups. Therefore, future studies could be done in other cultures or a cross-cultural endeavor may be crafted. Fourth, other moderators such as family incivility should be incorporated in the model to test how it influences the key variables.

\section{REFERENCES}

Agotnes, K. W., Einarsen, S. V., Hetland, J., \& Skogstad, A. (2018). The moderating effect of laissezfaire leadership on the relationship between co-worker conflicts and new cases of workplace bullying: A true prospective design. Human Resource Management Journal, 28(4), 555-568. doi: https://doi.org/10.1111/1748-8583.12200

Ahmad, A. (2008). Direct and indirect effects of work-family conflict on job performance. The Journal of International Management Studies, 3(2), 176-180.

Ahmad, M. S. (2011). Work ethics: An Islamic prospective. Journal of Human Sciences, $8(1), 850-859$.

Ajmal, M. U., \& Irfan, S. (2014). Understanding the moderating role of Islamic work ethics between job stress and work outcomes. IOSR Journal of Business and Management, 16(1), 62-67. doi: https://doi.org/10.9790/487X-16146267

Ali, A. (1988). Scaling an Islamic work ethic. The Journal of Social Psychology, 128(5), 575-583. doi: https://doi.org/10.1080/00224545.1988.9922911

Ali, A. J. (1992). The Islamic work ethic in Arabia. The Journal of Psychology, 126(5), 507-519. doi: https://doi.org/10.1080/00223980.1992.10543384

Alicia, A. G. (2000). Emotion regulation in the workplace: A new way to conceptualize emotional labor. Journal of Occupational Health Psychology, 5(1), 85-110.

Anwar, M., \& Shahzad, K. (2011). Impact of work-life conflict on perceived employee performance: Evidence from Pakistan. European Journal of Economics, Finance and Administrative Sciences, 31, 82-86.

Bartolome, F. (1972). Executives as human beings. Harvard Business Review, 50(6), 6269.

Baum, A., Singer, J. E., \& Baum, C. S. (1981). Stress and the environment. Journal of Social Issues, 37(1), 4-35. doi: https://doi.org/10.1111/j.1540-4560.1981.tb01056.x

Beekun, R. I. (1997). Islamic business ethics. Herndon, VA: International Institute of Islamic Thought (IIIT). 
Bellavia, G. M., \& Frone, M. R. (2005). Work-family conflict. In J. Barling, E. K. Kelloway, \& M. R. Frone, (Eds.), Handbook of work stress. New York, NY: Sage Publications. doi: https://doi.org/10.4135/9781412975995.n6

Bhagat, R. S. (1983). Effects of stressful life events on individual performance effectiveness and work adjustment processes within organizational settings: A research model. Academy of Management Review, 8(4), 660-671.

Bhuian, S. N., Menguc, B., \& Borsboom, R. (2005). Stressors and job outcomes in sales: A triphasic model versus a linear-quadratic-interactive model. Journal of Business Research, 58(2), 141-150. doi: https://doi.org/10.1016/S0148-2963(03)00132-2

Casper, W. J., Harris, C., Taylor-Bianco, A., \& Wayne, J. H. (2011). Workfamily conflict, perceived supervisor support and organizational commitment among Brazilian professionals. Journal of Vocational Behavior, 79(3), 640-652.

doi: https://doi.org/10.1016/j.jvb.2011.04.011

Cohen, J. (2013). Statistical power analysis for the behavioral sciences. New York, NY: Routledge. doi: https://doi.org/10.4324/9780203771587

Colquitt, J. A., Scott, B. A., Judge, T. A., \& Shaw, J. C. (2006). Justice and personality: Using integrative theories to derive moderators of justice effects. Organizational Behavior and Human Decision Processes, 100(1), 110-127. doi: https://doi.org/10.1016/j.obhdp.2005.09.001

Cortina, L. M., Magley, V. J., Williams, J. H., \& Langhout, R. D. (2001). Incivility in the workplace: Incidence and impact. Journal of Occupational Health Psychology, 6(1), 64-80. doi: https://doi.org/10.1037/1076-8998.6.1.64

Dastgeer, G., Rehman, A. U., \& Rahman, W. (2012). Examining data and measurement model specification in SEM: An illustration from management development. Journal of Business $\mathcal{F}$ Economics, 4(1), 62-88.

Din, M. U., \& Farooq, S. (2017). Effect of Islamic work ethics on employee well-being, job stress and turnover intention. Sarhad Journal of Management Sciences, 2(02), 157-163.

Ford, M. T., Heinen, B. A., \& Langkamer, K. L. (2007). Work and family satisfaction and conflict: A meta-analysis of cross-domain relations. Journal of Applied Psychology, 92(1), 57-80. doi: https://doi.org/10.1037/0021-9010.92.1.57

Fornell, C., \& Larcker, D. F. (1981). Evaluating structural equation models with unobservable variables and measurement error. Journal of Marketing Research, 18(1), 39-50.

French, K. A., Dumani, S., Allen, T. D., \& Shockley, K. M. (2018). A meta-analysis of work-family conflict and social support. Psychological Bulletin, 144(3), 284-314. doi: https://doi.org/10.1037/bul0000120

Frone, M. R. (2003), Work-family balance. In Handbook of occupational health psychology. Washington, DC, WA: American Psychological Association.

Frone, M. R., Russell, M., \& Cooper, M. L. (1992). Prevalence of workfamily conflict: Are work and family boundaries asymmetrically permeable? Journal of Organizational Behavior, 13(7), 723-729. doi: https://doi.org/10.1002/job.4030130708

Gibbons, C., Dempster, M., \& Moutray, M. (2011). Stress, coping and satisfaction in nursing students. Journal of Advanced Nursing, 67(3), 621-632.

doi: https://doi.org/10.1111/j.1365-2648.2010.05495.x 
Greenhaus, J. H., \& Beutell, N. J. (1985). Sources of conflict between work and family roles. Academy of Management Review, 10(1), 76-88.

Gutek, B. A., Searle, S., \& Klepa, L. (1991). Rational versus gender role explanations for work-family conflict. Journal of Applied Psychology, 76(4), 560-568.

doi: https://doi.org/10.1037/0021-9010.76.4.560

Hair, J. F., Black, W. C., Babin, B. J., Anderson, R. E., \& Tatham, R. L. (2006). Multivariate data analysis. Uppersaddle River, NJ: Pearson Prentice Hall.

Hayati, K., \& Caniago, I. (2012). Islamic work ethic: The role of intrinsic motivation, job satisfaction, organizational commitment and job performance. Procedia-Social and Behavioral Sciences, 65, 1102-1106. doi: https://doi.org/10.1016/j.sbspro.2014.05.148

Hill, E. J., Ferris, M., \& Martinson, V. (2003). Does it matter where you work? A comparison of how three work venues (traditional office, virtual office, and home office) influence aspects of work and personal/family life. Journal of Vocational Behavior, 63(2), 220-241. doi: https://doi.org/10.1016/S0001-8791(03)00042-3

Hobfoll, S. E. (1989). Conservation of resources: A new attempt at conceptualizing stress. American Psychologist, 44(3), 513-524. doi: https://doi.org/10.1037/0003-066X.44.3.513

Hockey, G. R. J. (1997). Compensatory control in the regulation of human performance under stress and high workload: A cognitive-energetical framework. Biological Psychology, 45(1-3), 73-93. doi: https://doi.org/10.1016/S0301-0511(96)05223-4

Holmes, T. H., \& Rahe, R. H. (1967). The social readjustment rating scale. Journal of Psychosomatic Research, 44(3), 513-524.

doi: https://doi.org/10.1016/0022-3999(67)90010-4

Hooper, D., Coughlan, J., Mullen, M. (2008). Structural equation modelling: Guidelines for determining model fit. Electronic Journal of Business Research Methods, 6(1), 5360 .

Hudson (2005). The case for work/life balance: Closing the gap between policy and practice. Retrieved from https://bit.ly/2II3xCK

Ilies, R., Johnson, M. D., Judge, T. A., \& Keeney, J. (2011). A withinindividual study of interpersonal conflict as a work stressor: Dispositional and situational moderators. Journal of Organizational Behavior, 32(1), 44-64. doi: https://doi.org/10.1002/job.677

Kahn, R. L., Wolfe, D. M., Quinn, R. P., Snoek, J. D., \& Rosenthal, R. A. (1964). Organizational stress: Studies in role conflict and ambiguity. Oxford, UK: John Wiley.

Keenan, A., \& Newton, T. J. (1985). Stressful events, stressors and psychological strains in young professional engineers. Journal of Organizational Behavior, 6(2), 151-156. doi: https://doi.org/10.1002/job.4030060206

Kemery, E. R., Mossholder, K. W., \& Bedeian, A. G. (1987). Role stress, physical symptomatology, and turnover intentions: A causal analysis of three alternative specifications. Journal of Organizational Behavior, 8(1), 11-23.

doi: https://doi.org/10.1002/job.4030080103

Kobasa, S. C. (1979). Stressful life events, personality, and health: An inquiry into hardiness. Journal of Personality and Social Psychology, 37(1), 1-11. doi: https://doi.org/10.1037/0022-3514.37.1.1 
Lazarus, R. S. (1966). Psychological stress and the coping process. New York, NY: McGraw-Hill.

Lazarus, R. S., \& Folkman, S. (1984). Stress, appraisal, and coping. New York, NY: Springer publishing company.

Leiter, M. P., \& Durup, M. J. (1996). Work, home, and in-between: A longitudinal study of spillover. The Journal of Applied Behavioral Science, 32(1), 29-47.

doi: https://doi.org/10.1177/0021886396321002

Letellier, M. C., Duchaine, C., Vézina, M., Aubé, K., Mantha-Bélisle, M. M., SultanTaïeb, H., ... \& Brisson, C. (2018). 880 Healthy Enterprise Standard (HES) evaluation: Impact on adverse psychosocial work factors and psychological distress. Occupational $\mathcal{E}$ Environmental Medicine, 75. Retrieved from https://bit.ly/2GO9NqT

Lim, S., Cortina, L. M., \& Magley, V. J. (2008). Personal and workgroup incivility: Impact on work and health outcomes. Journal of Applied Psychology, 93(1), 95-107.

doi: https://doi.org/10.1037/0021-9010.93.1.95

Mache, S., Bernburg, M., Vitzthum, K., Groneberg, D. A., Klapp, B. F., \& Danzer, G. (2015). Managing work-family conflict in the medical profession: Working conditions and individual resources as related factors. BMJ Open, 5(4), 1-9.

doi: https://doi.org/10.1136/bmjopen-2014-006871

Major, D. A., \& Germano, L. M. (2006). The changing nature of work and its impact on the work-home interface. In Work-Life Balance: A Psychological Perspective. New York, NY: Psychology Press.

Mirowsky, J., \& Ross, C. E. (2002). Measurement for a human science. Journal of Health and Social Behavior, 43(2), 152-170. doi: https://doi.org/10.2307/3090194

Mohamed, N., Karim, N. S. A., \& Hussein, R. (2010). Linking Islamic work ethic to computer use ethics, job satisfaction and organisational commitment in Malaysia. Journal of Business Systems, Governance and Ethics, 5(1), 13-23.

doi: https://doi.org/10.15209/jbsge.v5i1.175

Naqvi, S. N. H. (1981). Ethics and economics: An Islamic synthesis (Vol. 2). Leicester, UK: Islamic Foundation.

Nasr, S. H. (1984). Islamic work ethics. Hamdard Islamicus, 7(4), 25-35.

Netemeyer, R. G., Boles, J. S., \& McMurrian, R. (1996). Development and validation of work-family conflict and family-work conflict scales. Journal of Applied Psychology, 81(4), 400-410. doi: https://doi.org/10.1037/0021-9010.81.4.400

Pearson, C. M., Andersson, L. M., \& Wegner, J. W. (2001). When workers flout convention: A study of workplace incivility. Human Relations, 54(11), 1387-1419. doi: https://doi.org/10.1177/00187267015411001

Penney, L. M., \& Spector, P. E. (2005). Job stress, incivility, and Counterproductive Work Behavior (CWB): The moderating role of negative affectivity. Journal of Organizational Behavior, 26(7), 777-796. doi: https://doi.org/10.1002/job.336

Preacher, K. J., \& Hayes, A. F. (2008). Assessing mediation in communication research. In The Sage sourcebook of advanced data analysis methods for communication research. Thousand Oaks, CA: Sage Publications. doi: https://doi.org/10.4135/9781452272054.n2 
Rau, B. L., \& Hyland, M. A. M. (2002). Role conflict and flexible work arrangements: The effects on applicant attraction. Personnel Psychology, 55(1), 111-136. doi: https://doi.org/10.1111/j.1744-6570.2002.tb00105.x

Rawwas, M. Y., Javed, B., \& Iqbal, M. N. (2018). Perception of politics and job outcomes: Moderating role of Islamic work ethic. Personnel Review, 47(1), 74-94. doi: https://doi.org/10.1108/PR-03-2016-0068

Restubog, S. L. D., Scott, K. L., \& Zagenczyk, T. J. (2011). When distress hits home: The role of contextual factors and psychological distress in predicting employees' responses to abusive supervision. Journal of Applied Psychology, 96(4), 713-729. doi: https://doi.org/10.1037/a0021593

Rizk, R. (2008). Back to basics: An Islamic perspective on business and work ethics. Social Responsibility Journal, 4(1/2), 246-254. doi: https://doi.org/10.1108/17471110810856992

Rokhman, W. (2010). The effect of Islamic work ethics on work outcomes. EJBO-Electronic Journal of Business Ethics and Organization Studies, 15(1), 21-27.

Sadozai, A. M., Marri, M. Y. K., Zaman, H. M. F., Yousufzai, M. I., \& Nas, Z. (2013). Moderating role of Islamic work ethics between the relationship of organizational commitment and turnover intentions: A study of public sector of Pakistan. Mediterranean Journal of Social Sciences, 4(2), 767-775.

Sekaran, U., \& Bougie, R. (2016). Research methods for business: A skill building approach. West Sussex, UK: John Wiley \& Sons.

Spector, P. E., \& Jex, S. M. (1998). Development of four self-report measures of job stressors and strain: Interpersonal conflict at work scale, organizational constraints scale, quantitative workload inventory, and physical symptoms inventory. Journal of Occupational Health Psychology, 3(4), 356-367. doi: https://doi.org/10.1037/10768998.3.4.356

Wang, Y., Liu, L., Wang, J., \& Wang, L. (2012). Work-family conflict and burnout among Chinese doctors: The mediating role of psychological capital. Journal of Occupational Health, 54, 232-240. doi: https://doi.org/10.1539/joh.11-0243-OA

Yasbek, P. (2004). The business case for firm-level work-life balance policies: A review of the literature. Department of Labour, Wellington, UK. Retrieved from https://bit.ly/2IEW3As 